JIANG Chunyan, ZHAO Shuming

\title{
Does stage matter? The roles of organizational learning, social network, and corporate entrepreneurship in Chinese new ventures
}

\author{
(C) Higher Education Press and Springer-Verlag 2009
}

\begin{abstract}
This study examines the roles of organizational learning, social network and corporate entrepreneurship (CE) in Chinese new ventures at different developmental stages. Several conclusions are drawn from structural equation modeling based on a large sample of 676 new ventures. First, most of the recursive positive relationships are supported by data of the overall sample, such as those between radical $\mathrm{CE}$ and exploration, incremental $\mathrm{CE}$ and exploitation, and strong ties and exploitation. Second, in the sub-samples, we only find support for the recursive positive relationships between radical $\mathrm{CE}$ and exploration, and incremental $\mathrm{CE}$ and exploitation among all the three subsamples. Third, for new ventures in the early stage, relationships are emphasized concerning incremental CE, strong ties, and exploitation; for new ventures in the middle stage, new relationships concerning weak ties, exploration, and radical $\mathrm{CE}$ come into effect and previous ones still have influence; and for new ventures in the late stage, new relationships begin to dominate and old ones evade.
\end{abstract}

Keywords exploration learning, exploitation learning, weak ties, strong ties, incremental corporate entrepreneurship, radical corporate entrepreneurship

摘要 在总结国外学者有关组织学习、社会资本和公司创业研究的基础上, 概括了 它们之间相互关系的六个代表性模型, 并通过江苏和广东两省的 676 家新兴企业的 问卷调查数据进行了验证。结果表明, 组织学习、社会资本和公司创业相互促进,

Translated and revised from Guanli Kexue Xuebao 管理科学学报 ( Journal of Management Science in China), 2008, (6): 61-76

JIANG Chunyan $(\bowtie)$

School of Business, Nanjing University, Nanjing 210093, China

E-mail: cyjiang@nju.edu.cn

ZHAO Shuming

School of Business, Nanjing University, Nanjing 210093, China

E-mail: zhaosm@nju.edu.cn 
但这些相互促进关系在新兴企业发展的不同阶段发挥不同的作用。在早期企业比较 侧重于利用式学习、强关系和渐进式公司创业之间的促进关系; 而在中期企业则倾 向于在原有促进关系的基础上尝试探索式学习、弱关系和激进式公司创业; 经过不 断地调整, 在后期各种因素之间的相互促进关系逐渐清晰和明显, 并达到平衡。

关键词 探索式学习, 利用式学习, 弱关系, 强关系, 渐进式公司创业, 激进式 公司创业

\section{Introduction}

The survival and growth of new ventures are critical in transition economies since they provide a counterbalance to the loss of jobs in state-owned enterprises, and play crucial roles in stimulating economic growth. More researchers have argued that new ventures will play an increasing role in the future global economy, affecting developed and developing economies alike. Not surprisingly, many practitioners and researchers have been led to search for the factors that affect new venture performance (e.g., Baum et al., 2001; Peng and Health, 1996).

One of the major research streams in strategic management literature suggests that, for new ventures, the race for survival and growth is actually a race for learning because, given their "liabilities of newness and adolescence" (Stinchcombe, 1965), they need to become efficient in combining and assimilating diverse items of externally sourced "new" knowledge as well as their internal "old" knowledge base to align their strengths and weaknesses with the opportunities and threats in the environments (e.g., Kogut and Zander, 1992). An alternative research stream stresses based on the social network literature (Amburgey et al., 1993; Stuart et al., 1999) that survival and growth of new ventures are enhanced by establishing network ties with external stakeholders, thereby overcoming the liability of newness and adolescence by easy accesses to information, knowledge, and complementary resources (Cohen and Levinthal, 1990) as well as legitimacy (Delmar and Shane, 2004). Still another major research stream in entrepreneurship literature argues that survival and growth of new ventures are enhanced by corporate entrepreneurship (CE afterwards), that is, obtaining control over and recombining resources in a way characteristic of innovation, risk taking, and proactiveness (Chandler and Hanks, 1994; Schumpeter, 1934), pioneering new industries with technologically superior products (Henderson and Clark, 1990), and outperforming incumbents with firstmover advantages (Covin and Miles, 1999).

Given that organizational learning, social network, and CE represent three of the most influential factors that affect the survival and growth of new ventures (Baum et al., 2001; Delmar and Shane, 2004), it is important to understand their 
roles in new ventures. Previous studies tended to focus on one or two aspects of them and neglect the effects of developmental stages (e.g., Ireland et al., 2001; Peng and Luo, 2000; Li and Atuahene-Gima, 2001). Thus, they need to be supplemented in two main ways. First, these three factors are intricate with each other in that social network can influence and be influenced by organizational learning, $\mathrm{CE}$ can influence and be influenced by organizational learning and social network (Delmar and Shane, 2004; Zahra et al., 1999). Second, depending on particular circumstances of new ventures during different developmental stages, different combinations of these factors are needed (Miles and Snow, 1994).

Drawing primarily from the literature on strategic management and entrepreneurship, we constructed and examined a set of six alternative analytical models involving organizational learning, social network, and corporate entrepreneurship. The theoretical models represent six plausible configurations of these variables suggested by the literature. In addition to examining the models across the full sample of new ventures, we also analyze the three subsamples of new ventures during the early, middle, and late developmental stages. Age was used as segmentation variable because it has been repeatedly found to affect organizational level relationships (e.g., Amburgey and Rao, 1996; Baum, 1996).

China provides an ideal research setting for our study in investigating the intricate relationships among organizational learning, social network, and corporate entrepreneurship. First, Chinese new ventures face difficulties with organizational learning due to lack of the following factors: industrial clusters, well-developed networks of manufacturing and distribution, and legal protection of intellectual property (Lau et al., 2002). Second, Chinese new ventures, nevertheless, have long relied on their social network to access information and resources as well as legitimacy to overcome their shortcomings (e.g., Peng and Luo, 2000; Park and Luo, 2001; Xin and Pearce, 1996). Third, compared with long established SOEs, Chinese new ventures have little inherited organizational baggage from the socialist era and low fixed costs, therefore, they can operate entrepreneurially to be innovative, risk taking, and proactive to preempt competitors and to be the first movers in new niche markets to make up their liabilities of newness (Peng, 2001; Li and Atuahene-Gima, 2001, 2002). Finally, the government's initiative in establishing new and high-tech zones to upgrade industry standards, the revival in entrepreneurship, and the changing economy are giving birth to surges of new ventures and their roles in the economy are becoming more important. For example, according to the Second National Survey on Basic Units conducted in $2003^{1}$ completed recently, the number of

\footnotetext{
${ }^{1}$ Obtained from: http://www.ica.gov.cn/news2003/jmyw/06/1901.htm.
} 
new ventures from 1997 to 2001 (1.545 million) accounts for about 50 percent of the total number of the firms incorporated by the end of 2001. The number of employees, amount of capital, and annual sales revenues of these new ventures each account for more than 30 percent of the total. Therefore, it is critical, urgent, and indeed interesting to examine how Chinese new ventures, being relatively late entrants in the fields, can survive and succeed in the global economy by properly dealing with the intricate relationships among organizational learning, social network, and CE during different developmental stages.

\section{Literature review and model development}

In this section, we provide an overview of the literature on organizational learning, social network and CE. The purpose of the overview is twofold: First, to highlight the features of each factor that mark the theoretical boundaries of each construct; Second, to develop a rationale as to why the three factors should be studied in tandem. This discussion is followed by a specification of the six alternative theoretical models in which the three factors are interrelated in various configurations.

\subsection{Organizational learning}

Organizational learning has been proposed as a fundamental strategic process and the only sustainable competitive advantage of the future (DeGeus, 1988). The importance of organizational learning for a company's survival and effective performance has been emphasized in the literature (Barkema and Vermeulen, 1998; Huber, 1991). For new ventures, the race for survival and growth is like a race for learning because they must quickly overcome their "liabilities of newness and adolescence" (Amburgey et al., 1993; Stinchcombe, 1965) and establish for themselves the legitimacy and reduce the uncertainty enjoyed by more established firms (Ensley et al., 2002).

A key issue in the organizational learning literature is how successfully firms learn to exploit current knowledge and skills as well as to explore new knowledge and skills (March, 1991). Exploitation and exploration are especially important for new ventures. New ventures tend to possess less advanced technology and know-how and other forms of tangible and intangible assets compared to large established firms. Exploration of such assets is therefore critical for the development of their unique sources of competitive advantage over the existing competitors. Similarly, new ventures are likely to possess weaker recognition than large established firms. Exploitation of the existing technology and know-how for commercial application is therefore critical for the 
development of a stronger market position over the existing competitors. In essence, given the limited resource pool and recognition, whether new ventures become successful or unsuccessful would depend on how they successfully configure exploration and exploitation (Eisenhardt and Schoonhoven, 1990; Pfeffer and Salancik, 1978).

Exploration and exploitation have received wide attention in the field of organizational learning and provided the theoretical foundation for this study. Exploration includes "things captured by terms such as search, variation, risk taking, experimentation, play, flexibility, discovery, and innovation", whereas exploitation includes "such things as refinement, choice, production, efficiency, selection, implementation, and execution" (March, 1991). Exploration and exploitation describe different learning processes for organizational knowledge production. They affect how much and what kind of knowledge is produced.

A long tradition of research suggests that exploration and exploitation are in competition. Recognition and management of the tensions between exploration and exploitation are two of the critical challenges of organizational learning and therefore become a central requirement in a framework for organizational learning of new ventures. First, exploration and exploitation compete for limited resources and efforts (March, 1991); Second, exploration and exploitation require distinct organizational structures and cultures (Miller and Friesen, 1986); Finally, exploration and exploitation differ in the way to optimize a firm's fit with the external environment (Galbraith, 1973; Lawrence and Lorsch, 1967). Recently, researchers have argued that exploration and exploitation are complementary in nature, and hence organizations should engage in both, as opposed to either of exploration and exploitation (Levinthal and March, 1993). For example, Levinthal and March (1993) point out that "the basic problem confronting an organization is to engage in sufficient exploitation to ensure its current viability and, at the same time, to devote enough energy to exploration to ensure its future viability." Therefore, research in various fields has shifted its focus of interest from "whether" to "how" firms can achieve the complementarity between exploration and exploitation (Brown and Eisenhardt, 1997; Teece et al., 1997). However, Kyriakopoulos and Moorman (2004) argued that most efforts to create such complementarity are usually accomplished on a project-by-project basis depending on the degree of uncertainty (Olson et al., 1995). Therefore, there remains a need for additional conceptual treatments and empirical investigations regarding how firms, especially new ventures, configure exploration and exploitation in a more systematic manner. In addition, although the importance of the effects of exploration and exploitation on firm performance is widely acknowledged in developed economies (Ireland et al., 2001; NichollsNixon et al., 2000), research is still very limited in the contexts of transition 
economies such as China (e.g., Li and Atuahene-Gima, 2001, 2002; Peng and Health, 1996).

\subsection{Social network}

The importance of social network to survival and growth of new ventures has theoretical support from both resource-based and social theories. Institutional theory notes the legitimacy that can be gained through formal and informal attempts to social network with key agencies and individuals (Peng and Luo, 2000). Social network scholars argue that one can understand organizational phenomena and outcomes by considering not merely the presence of social relationships but also the overall pattern of relationships among people (Morrison, 2002). A useful way to differentiate social networks is the weak-tie-versusstrong-tie typology first advocated by Granovetter (1973). Strong ties are emotionally intense, frequent, and involving multiple types of relationships; enhance rapid transfer of overlap resources and information; and require large investments of time and energy to build and maintain. In contrast, weak ties are not emotionally intense, are infrequent, and are restricted to one narrow type of relationship; facilitate access to a wider base of novel or non-redundant resources and information; and demand relatively small investments of time and energy.

Empirical studies provide mixed support to the weak- and strong-tie arguments based on information, influence and control, and on solidarity benefits (Bruderl and Preisendorfer, 1998). Resolution of the debate regarding the benefit of strong versus weak ties may ultimately require a contingency approach (Rowley et al., 2000). Future research needs to shed more light on the factors that may determine when strong versus weak ties are likely to yield benefits. If, as suggested by Uzzi $(1996,1997)$, we can assume that firms can benefit more from balancing both weak and strong ties, rather than from relying exclusively on either of these kinds of ties, then we should be able to explain how the desirable balance should be achieved and how the trade-offs occur between these ties. Although the idea that social networks matter a great deal in transition economies is hardly controversial (Peng and Luo, 2000; Park and Luo, 2001; Xin and Pearce, 1996; Li and Athuahene-Gima, 2001), recent research suggests that the questions of how these social networks matter, under what circumstances, to what extent, and in what ways are still under investigation in the context of transition economies such as China (Peng, 2001).

\subsection{Corporate entrepreneurship}

CE has long been singled out as the key organizational process that contributes to firm survival, growth, and performance (Covin and Slevin, 1989; Lumpkin and 
Dess, 1996; Zahra et al., 1999). Similarly, a useful way to differentiate corporate entrepreneurship is the incremental-versus-radical typology advocated by Henderson and Clark (1990) on innovation. Incremental CE refers to the entrepreneurial initiatives that enforce or upgrade the existing components of a new product or market, while the core concepts and architectural knowledge remain unchanged. Radical CE involves the entrepreneurial initiatives that develop a new product or market, involving change of both the core concepts and architectural knowledge.

A hot debate has emerged concerning organizations' preferences for radical $\mathrm{CE}$ over incremental $\mathrm{CE}$ or vice versa, based on such considerations as firstmover advantages, economies of scale, legitimacy concern, and the "success trap". A complementarity between incremental and radical CE has been suggested to resolve the debates (e.g., Kazanjian et al., 2002). However, little attention has been paid in this research to such complementarity, or to how the complementarity can be achieved and its influences. Besides, most studies on CE are conducted in advanced market economies (e.g., Dess et al., 1997; Zahra et al., 1999), while much less has been done in transition economies.

\subsection{Hypothesized models}

While exploration and exploitation, strong and weak ties, and incremental and radical CE have been shown to be empirically distinct (March, 1991; Hansen, 1999; Henderson and Clark, 1990), previous studies have produced fragmented findings, particularly with regard to variations of different developmental stages. Therefore, we have specified six alternative analytical models that, in our opinion, are at least if not explicitly indicated in the literature. Each model, briefly described below and summarized in Fig. 1, was examined in the full sample of new ventures as well as in segmented samples (new ventures during the early, middle, and late stages).

Model 1

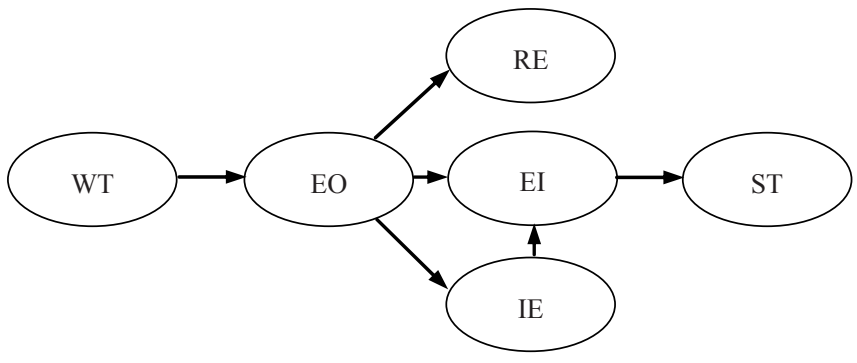


Model 2

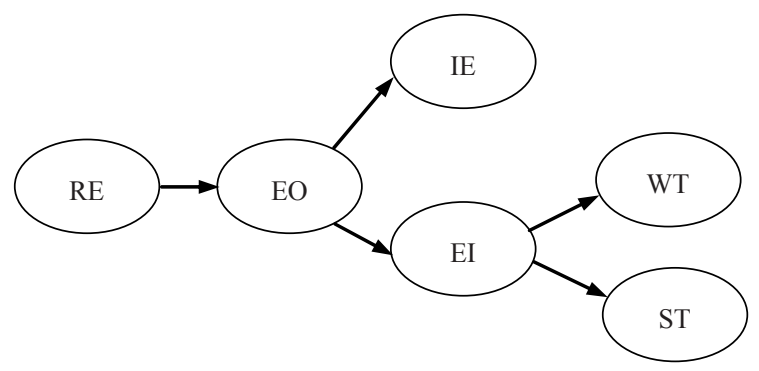

Model 3

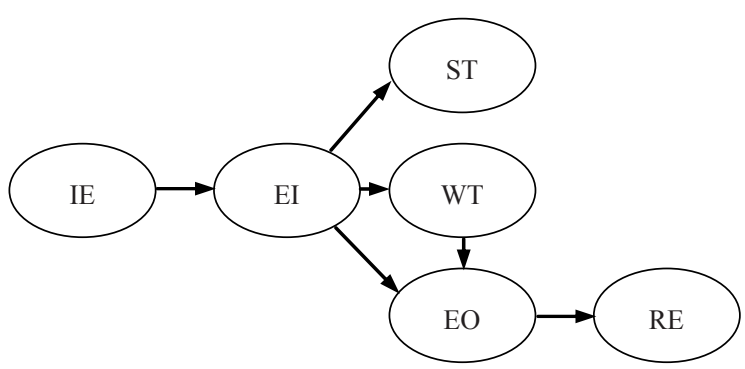

Model 4

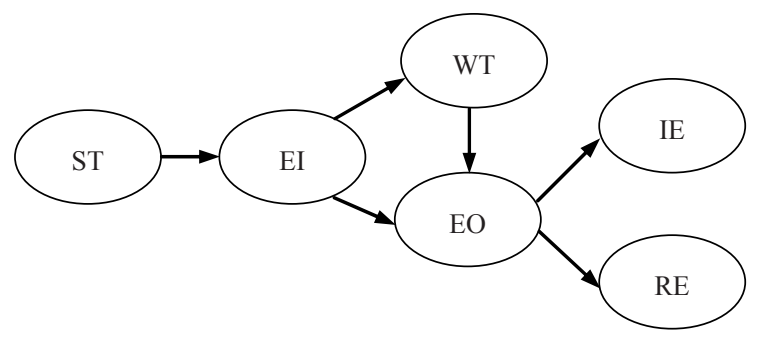

Model 5

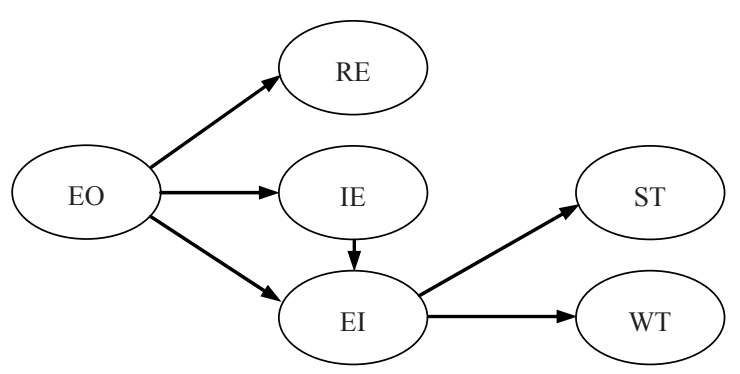


Model 6

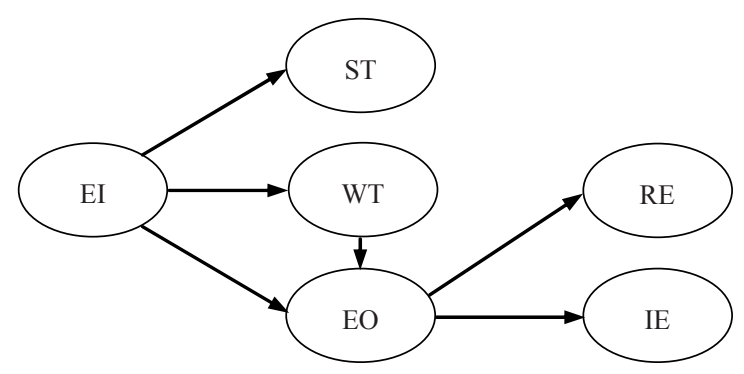

Fig. 1 Six hypothesized models of organizational learning, social network, and CE

Model 1: Weak ties (WT) have a direct positive effect on exploration (EO), which in turn has a significant and positive impact on radical corporate entrepreneurship (RE), incremental corporate entrepreneurship (IE), and exploitation (EI). IE has a direct positive effect on exploitation, which in turn has a significant and positive impact on strong ties (ST).

Model 2: Radical CE has a direct positive effect on exploration, which in turn has a significant and positive impact on both incremental CE and exploitation. Incremental $\mathrm{CE}$ has a direct positive effect on exploitation, which in turn has a significant and positive impact on strong ties and negative impact on weak ties.

Model 3: Incremental CE has a direct positive effect on exploitation, which in turn has a significant and positive impact on strong ties and negative impact on weak ties and exploration. Weak ties have a direct positive effect on exploration, which in turn has a significant and positive impact on radical CE.

Model 4: Strong ties have a direct positive effect on exploitation, which in turn has a significant and negative impact on both weak ties and exploration. Weak ties have a direct positive effect on exploration, which in turn has a significant and positive impact on both radical and incremental CE.

Model 5: Exploration has a positive effect on radical CE, incremental CE, and exploitation. Incremental CE has a direct positive effect on exploitation, which in turn has a significant and positive impact on strong ties and negative impact on weak ties.

Model 6: Exploitation has a positive effect on strong ties and a negative effect on both weak ties and exploration. Weak ties have a direct positive effect on exploration, which in turn has a significant and positive impact on both radical and incremental CE.

The examination of the six models is conducted without assuming that a particular model will outperform the others. Three main reasons support the use of an unconstrained analytical approach. First, previous studies have provided 
inconsistent evidence regarding the relationships among these six key constructs (see Section 2). Second, no previous studies have included all six constructs simultaneously in an empirical analysis. Third, no previous studies have simultaneously examined even subset of these constructs in new ventures during different developmental stages.

\section{Methods}

\subsection{Sample and procedures}

We sent the questionnaire to CEOs of a random sample of 1250 manufacturing firms (250 each in Nanjing, Wuxi, Zhangjiagang, Guangzhou and Dongguan City), using municipal governments' directories. Consistent with an accepted definition of a new venture ( $\mathrm{Li}$ and Atuahene-Gima, 2001, 2002), all sampled firms were eight years old or younger. Jiangsu Province (Nanjing, Wuxi, and Zhangjiagang City) and Guangdong Province (Guangzhou and Dongguan City) were selected as sample locations for the reasons that (1) they are ranked the first and third respectively in terms of the number of new ventures based on the report of the second national survey of basic unit and (2) according to other similar studies (Luo and Peng, 1999), the policies, rules, and measures adopted in the firms in Jiangsu and Guangdong provinces are representative of those firms in the whole country owing to their leading roles in economic reform.

We collected the data through on-site surveys, which offered respondents an opportunity to ask for clarifications about the issues under study. We also restricted the recall time frame to three years and assured confidentiality to all respondents. Previous research had indicated that Chinese managers tended to provide reliable data under such assurance ( $\mathrm{Li}$ and Atuahene-Gima, 2001). Meanwhile, respondents were motivated to provide valid data by offering a summary of the research results and a free workshop on the research findings. As McGrath (2001) argues, the promise of useful feedback ensures that respondents become professionally interested, conscientious, and committed to provide accurate data.

Finally, we received 696 completed questionnaires, of which 20 were deemed not usable because of missing data. The final sample size was 676 (244 from Zhangjiagang, 87 from Wuxi, 89 from Nanjing, 128 from Guangzhou, and 128 from Dongguan). Thus, the effective response rate was about 54.1\% (676/1 250). Our informants were all $\mathrm{CEOs}^{2}$ and regarded knowledgeable about the issues under study. Table 1 summarizes the main characteristics of the sample. These percentages are generally consistent with those published by the Second National

\footnotetext{
${ }^{2}$ The main focus of the national science fund project is the professionalization of CEOs.
} 
Survey on Basic Units (2003), most representative sample of new ventures in China. Finally, we compared the responding firms with those of non-respondents and found no statistically significant differences in terms of size $(F=0.88, p>0.10)$ and age $(F=0.33, p>0.10)$. This evidence indicates that there was no important non-respondent bias in our sample.

Table 1 Main characteristics of the sample

\begin{tabular}{|c|c|c|}
\hline $\begin{array}{r}\text { Firm Characteristics } \\
\end{array}$ & No. of firms & Percentage \\
\hline \multicolumn{3}{|l|}{ Firm size (No. of employees) } \\
\hline Less than 100 & 196 & 29.0 \\
\hline $100-500$ & 301 & 44.5 \\
\hline $500-1000$ & 110 & 16.3 \\
\hline $1000-2000$ & 60 & 8.9 \\
\hline More than 2000 & 9 & 1.3 \\
\hline Total & 676 & 100.0 \\
\hline \multicolumn{3}{|l|}{ Ownership type } \\
\hline State-owned & 24 & 3.6 \\
\hline Foreign-owned & 45 & 6.7 \\
\hline Joint stock & 86 & 12.7 \\
\hline Private & 405 & 59.9 \\
\hline Collective & 98 & 14.5 \\
\hline Others & 18 & 2.6 \\
\hline Total & 676 & 100.0 \\
\hline \multicolumn{3}{|l|}{ Firm age } \\
\hline Less than 3 years old & 289 & 42.8 \\
\hline $3-5$ years old & 219 & 32.4 \\
\hline More than 5 years old & 168 & 24.8 \\
\hline Total & 676 & 100.0 \\
\hline \multicolumn{3}{|l|}{ Industry } \\
\hline Electronic information & 322 & 47.6 \\
\hline Optical-mechanical \& electric products & 110 & 16.3 \\
\hline Pharmaceutical \& bioengineering & 96 & 14.2 \\
\hline Textile & 85 & 12.6 \\
\hline Others & 63 & 9.3 \\
\hline Total & 676 & 100.0 \\
\hline \multicolumn{3}{|l|}{ Location } \\
\hline Zhangjiagang & 244 & 36.1 \\
\hline Nanjing & 89 & 13.2 \\
\hline Wuxi & 87 & 12.9 \\
\hline Guangzhou & 128 & 18.9 \\
\hline Dongguan & 128 & 18.9 \\
\hline Total & 676 & 100.0 \\
\hline
\end{tabular}

A common method variance problem can result from collecting all variables from the same respondent in the same survey. Our data may suffer from common method variance. Following Podsakoff and Organ (1986) and Podsakoff et al. 
(2003), we dealt with common method variance problem through the design of the study's procedures and statistical controls. Procedurally, we protected respondent anonymity, assured respondents that there are no right or wrong answers and that they should answer questions as honestly as possible, counterbalanced question order, and improved scale items designed by the previous case studies on defining clear and familiar terms, avoiding vague concepts, keeping questions simple, specific, and concise, and so on. Statistically, we used the Harman one factor test to examine the extent of common method variance in our data. A principal components factor analysis with an unrotated solution yielded six factors with eigenvalues greater than 1.0, accounting for 73.2 percent of the total variance. The largest variance explained by factor 1 is 32.6 percent, which suggests that no single factor accounted for the majority of the covariance in the variables. From this evidence, we inferred that no substantial amount of common method variance was present in our data set.

\subsection{Measures}

Exploration and exploitation Scholars frequently measure learning processes by subjective management assessments because of the lack of good objective proxies (e.g., McGrath, 2001; Yli-Renko et al., 2001; Zahra et al., 2000). To tap the aspects of exploration and exploitation, we adopted the ten items (five for each) developed by Atuahene-Gima (2003) based on McGrath (2001) and others to develop the constructs.

Incremental and radical CE Incremental and radical CE were measured by eight items adapted from He and Wong (2004). Respondents indicate the extent to which top managers of the firm will evaluate the statements concerning how firms tend to divide attention and resources to new products development in the last three years.

Strong ties and weak ties Strong and weak ties were measured by eight items adapted from Collins and Clark (2003). Respondents evaluated the range, frequency, duration, and emotional intensity for their contacts in nine external categories of actors for weak ties (external board members, suppliers, customers, financial institutions, competitors, alliance partners, government agencies, trade associations, and "other external") and four internal categories for strong ties (sales and marketing, research and development, production and operations, and "other internal"). Because top managers potentially have hundreds of contacts, respondents were asked to rate the average relationship within each category.

A multistage process was used to assess construct validity with the guidelines outlined by Anderson and Gerbing (1988). We first examined item-to-total 
correlations and performed an exploratory factor analysis (EFA) for each scale since the measures had been modified from previous studies. Then we conducted confirmatory factor analysis (CFA) to test for the unidimensionality and convergent validity of the constructs. As the results show (see Table 2), six factors were extracted from the 26 items, which explained 73.2 percent of the total variance.

Table 2 EFA results of measures

\begin{tabular}{ll}
\hline Constructs and source & F1 \\
\hline Strong \& Weak ties (Collins and Clark, 2003; Peng & \\
and Luo, 2000) \\
F1 Strong ties \\
Please circle the number best describing the \\
extent to which you have utilized personal \\
ties, networks, and connections during the \\
past three years with: (1) sales \& marketing, \\
(2) research \& development, (3) production \& \\
operations, and (4) "other internal" \\
1. How many contacts do you have in each category & 0.88 \\
2. How frequent do you contact with your contacts & 0.90 \\
3. How long have you known these critical contacts & 0.87 \\
4. How close is your relationship with these contacts & 0.88
\end{tabular}

F2 Weak ties

Please circle the number best describing the extent to which you have utilized personal ties, networks, and connections during the past three years with: (1) external board members, (2) suppliers, (3) customers, (4) financial institutions, (5) competitors, (6) alliance partners, (7) government agencies, (8) trade associations, and (9) "other external"

1. How many contacts do you have in each category

2. How frequent do you contact with your contacts

3. How long have you known these critical contacts

4. How close is your relationship with these contacts

Radical \& Incremental CE (He and Wong, 2004)

In general, the top managers of my firm favor to ...

F3 Incremental CE

1. Improve existing product quality $\quad 0.72$

2. Improve production flexibility $\quad 0.80$

3. Reduce production cost $\quad 0.85$

4. Improve yield or reduce material consumption $\quad 0.79$

F4 Radical CE

1. Introduce new generation of products 


\begin{tabular}{|c|c|c|c|c|c|c|}
\hline \multirow[b]{2}{*}{ Constructs and source } & \multicolumn{6}{|c|}{ (Continued) } \\
\hline & F1 & F2 & $\mathrm{F} 3$ & $\mathrm{~F} 4$ & F5 & F6 \\
\hline 2. Extend product range & & & & 0.82 & & \\
\hline 3. Open up new markets & & & & 0.76 & & \\
\hline 4. Enter new technology fields & & & & 0.65 & & \\
\hline \multicolumn{7}{|l|}{$\begin{array}{l}\text { Exploration \& Exploitation (Atuahene-Gima, 2003; } \\
\text { McGrath, 2001) }\end{array}$} \\
\hline \multicolumn{7}{|l|}{$\begin{array}{l}\text { To what extent does each of the following } \\
\text { statements describe your firm's behavior for } \\
\text { product information acquisition and use }\end{array}$} \\
\hline \multicolumn{7}{|l|}{ F5 Exploration } \\
\hline 1.Collect information on totally new products & & & & & 0.66 & \\
\hline $\begin{array}{l}\text { 2.Search for products information involving } \\
\text { experimentation and high risk }\end{array}$ & & & & & 0.79 & \\
\hline $\begin{array}{l}\text { 3. Search for products information that took the } \\
\text { firm beyond its current experiences }\end{array}$ & & & & & 0.75 & \\
\hline \multicolumn{7}{|l|}{ F6 Exploitation } \\
\hline $\begin{array}{l}\text { 1.Undertake products searching activities that } \\
\text { we know we could do well rather than those } \\
\text { that may lead to mistakes }\end{array}$ & & & & & & 0.79 \\
\hline $\begin{array}{l}\text { 2. Undertake methods and solutions to products } \\
\text { problems that build on the firm's experience }\end{array}$ & & & & & & 0.61 \\
\hline $\begin{array}{l}\text { 3. Search for products information and ideas that } \\
\text { took the firm into existing products areas }\end{array}$ & & & & & & 0.62 \\
\hline Alpha coefficient & 0.95 & 0.95 & 0.86 & 0.81 & 0.72 & 0.70 \\
\hline Eigen value & 7.2 & 2.7 & 2.4 & 1.6 & 1.2 & 1.1 \\
\hline Cumulative proportion of variance accounted for & 15.8 & 31.6 & 44.7 & 56.5 & 65.0 & 73.2 \\
\hline
\end{tabular}

The standardized loadings are highly significant for the items, suggesting that all of these indicators are similarly responsive to changes in the underlying constructs they are purported to measure (two items each from exploration \& exploitation were deleted because of their inconclusive factor loading patterns). The fit indexes indicate that the model fit the data well $\left(\chi^{2}(194)=673.04, p<0.01 ; \mathrm{CFI}=0.96\right.$; RMSEA $\left.=0.062, \mathrm{NNFI}=0.97, \mathrm{IFI}=0.97\right)$. All items loaded on their respective constructs and each loading was large and significant at the 0.01 level, which indicate that convergent validity of the constructs is acceptable.

Next, we assessed discriminant validity by comparing Harman's 1-factor model, 3-factor model and our 6-factor model. Results of 1-factor model were $\chi^{2}(209)=5264.58, p<0.01 ; \mathrm{RMSEA}=0.23 ; \mathrm{CFI}=0.70 ; \mathrm{IFI}=0.70$; and NNFI $=0.67$, which displayed a poor model fit. Similarly, results of 3-factor model displayed a poor model fit with fit indexes of $\chi^{2}(206)=3$ 746.21, $p<0.01$; RMSEA $=0.18$; $\mathrm{CFI}=0.79$; IFI $=0.79$; and $\mathrm{NNFI}=0.76$. We compared 1 -factor model and 3-factor model with the 6-factor model. The significant chi-square change $\left(\Delta \chi^{2}(15)\right.$ 
$\left.=4591.54, p<0.01 ; \Delta \chi^{2}(12)=3073.17, p<0.01\right)$ indicated that the respondents of this study could distinguish the six constructs well.

Finally, we assessed the reliability of the constructs with Cronbach's coefficient alpha. All scales indicated good reliabilities with high alpha coefficients exceeding 0.70 (see Table 2).

Means, standard deviations, and correlations among all variables are presented in Table 3. All correlations are significant at 0.01 level. Examination of the correlations among variables indicates the following relationships. Exploration had a positive correlation with exploitation $(r=0.36)$. A positive relationship was also found between radical $\mathrm{CE}$ and incremental $\mathrm{CE}(r=0.35)$ and between strong ties and weak ties $(r=0.46)$. Exploration had stronger correlations with radical $\mathrm{CE}$ and weak ties than with incremental $\mathrm{CE}$ and strong ties $(r=0.48$ and $r=0.29$ versus $r=0.27$ and $r=0.24)$. While, exploitation had stronger correlations with incremental $\mathrm{CE}$ and strong ties than with radical $\mathrm{CE}$ and weak ties $(r=0.46$ and $r=0.32$ versus $r=0.32$ and $r=0.24)$. Radical $\mathrm{CE}$ had a stronger correlation with weak ties $(r=0.31)$ than with strong ties $(r=0.26)$; on the contrary, incremental CE had a stronger correlation with strong ties $(r=0.41)$ than with weak ties $(r=0.24)$.

Table 3 Means, standard deviations and correlations of variables

\begin{tabular}{lcccccccc}
\hline Variables & Mean & S.D. & Exploration Exploitation Radical Incremental & Weak & Strong \\
ties & ties \\
\hline Exploration & 3.23 & 0.98 & 1 & & & & & \\
Exploitation & 3.74 & 0.77 & 0.36 & 1 & & & & \\
Radical CE & 3.32 & 1.05 & 0.48 & 0.32 & 1 & & & \\
Incremental CE & 3.92 & 1.03 & 0.27 & 0.46 & 0.35 & 1 & & \\
Weak ties & 3.69 & 1.17 & 0.29 & 0.24 & 0.31 & 0.24 & 1 & \\
Strong ties & 4.76 & 1.20 & 0.24 & 0.32 & 0.26 & 0.41 & 0.46 & 1 \\
\hline
\end{tabular}

Note: All correlations are significant at 0.01 level. $N$ ranges from 661 to 676.

In all, the analyses supported reliabilities and adequate convergent and discriminant validities for each of the constructs. As such, the measures can be used in later statistical analyses in this study.

\subsection{Methodology}

We employed structural equation modeling (SEM) to assess the fit of the proposed models. LISREL 8.54 was used to evaluate the fit of the alternative measurement and structural models. As a Chi-square $\left(\chi^{2}\right)$ test is sensitive to sample size, overall model fit was also examined by various fit indices including root-mean-square error of approximation (RMSEA) (Steiger, 1990); non-normed fit index (NNFI), incremental fit index (IFI) (Bollen, 1989); and the comparative 
fit index (CFI) (Bentler, 1990). A good model fit is shown when RMSEA is below 0.08 (Browne and Cudeck, 1993); and NNFI, IFI and CFI score are above 0.90 (Byrne, 1998).

\section{Results}

The results of the six hypothesized models shown in Figure 1 can be found in Tables 4-Table 7. Table 4 reports the results of the six models for the total sample. Tables 5-Table 7 report corresponding results for the segmented samples (i.e. new ventures during the early, middle, and late stages).

\subsection{Total sample}

In the overall analysis, all six models were found to be plausible solutions to the variables examined with good fit statistics: $\chi^{2}(194)=673.04, p<0.01$; RMSEA $=0.062 ; \mathrm{CFI}=0.97$; IFI $=0.97$; and $\mathrm{NNFI}=0.97$. Table 4 shows the relationships among organizational learning, social network, and CE in the total sample.

Table 4 Summary of relationships in total sample $(N=676)$

\begin{tabular}{|c|c|c|c|c|c|c|c|}
\hline \multicolumn{2}{|c|}{ Paths } & Model 1 & Model 2 & Model 3 & Model 4 & Model 5 & Model 6 \\
\hline & STIE & $0.41^{* * *}$ & $0.41^{* * *}$ & & & $0.41^{* * *}$ & \\
\hline & RCE & $0.10^{*}$ & & $0.10^{*}$ & $0.10^{*}$ & & $0.10^{*}$ \\
\hline \multirow[t]{6}{*}{ WTIE } & EXPLOIT & $0.06^{*}$ & & & & & \\
\hline & ICE & $0.17^{* * *}$ & & & 1 & & 1 \\
\hline & EXPLOR & $0.26^{* * *}$ & & $0.15^{* * *}$ & $0.15^{* * *}$ & & $0.15^{* * *}$ \\
\hline & & & & & & & \\
\hline & STIE & 1 & & & & 1 & \\
\hline & RCE & $0.62^{* * *}$ & & $0.62^{* * *}$ & $0.62^{* * *}$ & $0.74^{* * *}$ & $0.62^{* * *}$ \\
\hline \multirow[t]{6}{*}{ EXPLOR } & EXPLOIT & $0.22^{* * *}$ & $0.23^{* * *}$ & & & $0.23^{* * *}$ & \\
\hline & ICE & $0.33^{* * *}$ & $0.18^{*}$ & & 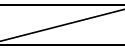 & $0.18^{*}$ & 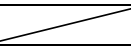 \\
\hline & WTIE & & 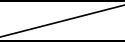 & & & 1 & \\
\hline & & & & & & & \\
\hline & STIE & $0.29^{* * *}$ & $0.29^{* * *}$ & $0.32^{* * *}$ & & $0.29^{* * *}$ & \\
\hline & RCE & $0.20^{*}$ & & $0.20^{*}$ & & & $0.20^{*}$ \\
\hline \multirow[t]{6}{*}{ ICE } & EXPLOIT & $0.33^{*}$ & $0.34^{* * *}$ & $0.41^{* * *}$ & & $0.34^{* * *}$ & \\
\hline & EXPLOR & & & 1 & & & \\
\hline & WTIE & & 1 & 1 & & 1 & \\
\hline & & & & & & & \\
\hline & STIE & $0.33^{*}$ & $0.33^{*}$ & $0.51^{* * *}$ & & $0.33^{*}$ & $0.85^{* * *}$ \\
\hline & RCE & $\sqrt{2}$ & & 7 & & & \\
\hline
\end{tabular}

(To be continued) 
(Continued)

\begin{tabular}{|c|c|c|c|c|c|c|c|}
\hline \multicolumn{2}{|c|}{ Paths } & \multirow[t]{2}{*}{ Model 1} & \multirow[t]{2}{*}{ Model 2} & \multirow[t]{2}{*}{ Model 3} & \multirow{2}{*}{$\frac{\text { Model } 4}{0.88^{* * *}}$} & \multirow[t]{2}{*}{ Model 5} & \multirow{2}{*}{$\frac{\text { Model } 6}{0.91^{* * *}}$} \\
\hline EXPLOIT & ICE & & & & & & \\
\hline & WTIE & & $0.30^{*}$ & $0.29^{*}$ & $0.26^{*}$ & $0.30^{*}$ & $0.26^{*}$ \\
\hline & EXPLOR & & & $0.60^{* * *}$ & $0.60^{* * *}$ & & $0.60^{* * *}$ \\
\hline & & & & & & & \\
\hline & STIE & & 1 & & & 1 & \\
\hline & WTIE & & $0.15^{*}$ & & & $0.15^{*}$ & \\
\hline \multirow[t]{6}{*}{$\mathrm{RCE}$} & ICE & & $0.29^{* * *}$ & & $0.17^{*}$ & $0.29^{* * *}$ & \\
\hline & EXPLOR & & $0.49^{* * *}$ & & & & \\
\hline & EXPLOIT & & 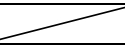 & & & 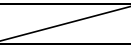 & \\
\hline & & & & & & & \\
\hline & WTIE & & & $0.37^{* * *}$ & $0.36^{* * *}$ & & $0.36^{* * *}$ \\
\hline & ICE & & & & $0.17^{* * *}$ & & $0.17^{* * *}$ \\
\hline \multirow[t]{3}{*}{ STIE } & EXPLOR & & & & 1 & & 1 \\
\hline & EXPLOIT & & & & $0.24^{* * *}$ & & \\
\hline & $\mathrm{RCE}$ & & & 1 & 1 & & 1 \\
\hline \multicolumn{8}{|c|}{$\begin{array}{l}\text { EXPLORE } \leftrightarrow \text { EXPLOIT; WTIE } \leftrightarrow \text { STIE; ICE } \leftrightarrow \text { RCE; } \\
\text { RCE } \leftrightarrow \text { EXPLORE; ICE } \leftrightarrow \text { EXPLOIT; } \\
\text { STIE } \leftrightarrow \text { EXPLOIT; WTIE } \leftrightarrow \text { EXPLOIT; WTIE } \rightarrow \text { EXPLORE } \\
\text { RCE } \leftrightarrow \text { WTIE; ICE } \leftrightarrow \text { STIE }\end{array}$} \\
\hline
\end{tabular}

Note: WTIE-Weak ties; STIE-Strong ties; RCE—Radical CE; ICE-Incremental CE;

EXPLOIT-Exploitation; EXPLORE-Exploration. The same in tables below.

In sum, we found supports for existences of most recursive positive relationships between weak and strong ties, exploration and exploitation, radical $\mathrm{CE}$ and incremental $\mathrm{CE}$, radical $\mathrm{CE}$ and exploration, incremental $\mathrm{CE}$ and exploitation, strong ties and exploitation, weak ties and radical $\mathrm{CE}$, and strong ties and incremental CE. However, we just found the positive effects of weak ties on exploration and did not find exploration's feedback effect on weak ties. Unexpectedly, we found recursive positive relationships between weak ties and exploitation. These results suggest that the intricacies of the relationships among social network, $\mathrm{CE}$, and organizational learning need to be examined from the perspective of system dynamics in order to enhance both theoretical and practical relevance of the studies.

\subsection{Sub-samples}

Then, we adopted a cross-sectional comparison of different ventures at varying stages of development to intimate the evolutionary process of the key recursive relationships in the hypothesized models by separating the total sample into three sub-samples according to firm age, that is, ventures less than three years old, from three years old to five years old, and more than five years old. 
4.2.1 Sample 1 (new ventures in early stage—-less than 3 years old)

Similarly, all six models were found to be equally plausible solutions with good fit statistics $\left(\chi^{2}(194)=499.04, p<0.01\right.$; RMSEA $=0.076$; CFI $=0.96$; IFI $=0.96$; and $\mathrm{NNFI}=0.95$ ). Table 5 shows the relationships among organizational learning, social network, and CE in Sample 1.

Table 5 Summary of relationships in Sample $1(N=289)$

\begin{tabular}{|c|c|c|c|c|c|c|c|}
\hline \multicolumn{2}{|c|}{ Paths } & \multirow{2}{*}{$\frac{\text { Model 1 }}{0.34^{* * *}}$} & \multirow{2}{*}{$\begin{array}{c}\text { Model } 2 \\
0.34^{* * *}\end{array}$} & \multirow[t]{2}{*}{ Model 3} & \multirow[t]{2}{*}{ Model 4} & \multirow{2}{*}{$\frac{\text { Model } 5}{0.34^{* * * *}}$} & \multirow[t]{2}{*}{ Model 6} \\
\hline & STIE & & & & & & \\
\hline & RCE & 1 & & 1 & 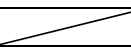 & & 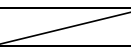 \\
\hline \multirow[t]{6}{*}{ WTIE } & EXPLOIT & $0.10^{*}$ & & & & & \\
\hline & ICE & $0.24^{* * * *}$ & & & $\infty$ & & 1 \\
\hline & EXPLOR & $0.17^{*}$ & & + & 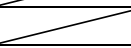 & & 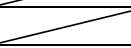 \\
\hline & & & & & & & \\
\hline & STIE & 1 & 1 & & & 1 & \\
\hline & RCE & $0.63^{* * *}$ & & $0.63^{* * *}$ & $0.62^{* * * *}$ & $0.76^{\text {*** }}$ & $0.63^{* * *}$ \\
\hline \multirow[t]{6}{*}{ EXPLOR } & EXPLOIT & $0.24^{* * * *}$ & $0.21^{*}$ & & & $0.21^{*}$ & \\
\hline & ICE & $0.30^{* * * *}$ & $>$ & & $\infty$ & $>$ & 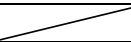 \\
\hline & WTIE & & 1 & & & 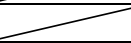 & \\
\hline & & & & & & & \\
\hline & STIE & $0.28^{*}$ & $0.28^{*}$ & $0.32^{*}$ & & $0.28^{*}$ & \\
\hline & RCE & $>$ & & $>$ & & & 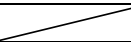 \\
\hline \multirow[t]{6}{*}{ ICE } & EXPLOIT & $0.44^{* * * *}$ & $0.45^{* * *}$ & $0.54^{* * *}$ & & $0.45^{* * *}$ & \\
\hline & EXPLOR & & & 1 & & & \\
\hline & WTIE & & 1 & 1 & & $>$ & \\
\hline & & & & & & & \\
\hline & STIE & $\infty$ & 1 & $0.44^{*}$ & & 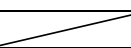 & $0.72^{* * *}$ \\
\hline & RCE & $>$ & & $>$ & 1 & & 1 \\
\hline \multirow[t]{6}{*}{ EXPLOIT } & ICE & & & & $0.80^{* * *}$ & & $0.82^{* * *}$ \\
\hline & WTIE & & 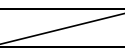 & 1 & $0.26^{*}$ & 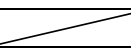 & $0.26^{*}$ \\
\hline & EXPLOR & & & $0.63^{* * *}$ & $0.60^{* * *}$ & & $0.60^{* * * *}$ \\
\hline & & & & & & & \\
\hline & STIE & & 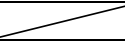 & & & 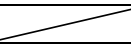 & \\
\hline & WTIE & & 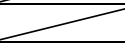 & & & 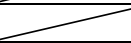 & \\
\hline \multirow[t]{6}{*}{ RCE } & ICE & & $0.22^{*}$ & & $\infty$ & $0.22^{*}$ & \\
\hline & EXPLOR & & $0.47^{* * * *}$ & & & & \\
\hline & EXPLOIT & & 1 & & & 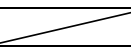 & \\
\hline & & & & & & & \\
\hline & WTIE & & & $0.32^{* * *}$ & $0.32^{* * *}$ & & $0.32^{* * *}$ \\
\hline & ICE & & & & $0.15^{*}$ & & $0.15^{*}$ \\
\hline \multirow[t]{3}{*}{ STIE } & EXPLOR & & & T & 1 & & 1 \\
\hline & EXPLOIT & & & & $0.31^{* * *}$ & & \\
\hline & RCE & & & $\infty$ & 1 & & $\infty$ \\
\hline \multicolumn{8}{|c|}{$\begin{array}{l}\text { EXPLORE } \leftrightarrow \text { EXPLOIT; WTIE } \leftrightarrow \text { STIE } \\
\text { RCE } \leftrightarrow \text { EXPLORE; ICE } \leftrightarrow \text { EXPLOIT; } \\
\text { ICE } \leftrightarrow \text { STIE }\end{array}$} \\
\hline
\end{tabular}


In sum, we found supports for recursive positive relationships between weak and strong ties, exploration and exploitation, radical CE and exploration, incremental $\mathrm{CE}$ and exploitation, and strong ties and incremental CE. However, we did not find the recursive positive relationships between radical $\mathrm{CE}$ and incremental $\mathrm{CE}$, weak ties and exploration, strong ties and exploitation, and radical $\mathrm{CE}$ and weak ties.

4.2.2 Sample 2 (new ventures in middle stage-from 3 years old to 5 years old)

All six models were found to be marginally plausible solutions $\left(\chi^{2}(194)=467.08\right.$, $p<0.01$; RMSEA $=0.08$; CFI $=0.95$; IFI $=0.95$; and NNFI $=0.94)$. Table 6 shows the relationships among organizational learning, social network, and CE in Sample 2.

Table 6 Summary of relationships in Sample $2(N=219)$

\begin{tabular}{|c|c|c|c|c|c|c|c|}
\hline \multicolumn{2}{|c|}{ Paths } & \multirow{2}{*}{$\frac{\text { Model 1 }}{0.48^{* * *}}$} & \multirow{2}{*}{$\begin{array}{c}\text { Model } 2 \\
0.48^{* * *}\end{array}$} & \multirow[t]{2}{*}{ Model 3} & \multirow[t]{2}{*}{ Model 4} & \multirow{2}{*}{$\begin{array}{c}\text { Model } 5 \\
0.48^{* * *}\end{array}$} & \multirow[t]{2}{*}{ Model 6} \\
\hline & STIE & & & & & & \\
\hline & RCE & 1 & & & 1 & & 1 \\
\hline \multirow[t]{6}{*}{ WTIE } & EXPLOIT & 1 & & & & & \\
\hline & ICE & $0.15^{*}$ & & & 1 & & 1 \\
\hline & \begin{tabular}{|l|} 
EXPLOR \\
\end{tabular} & $0.29^{* * *}$ & & $0.25^{* * *}$ & $0.25^{* * *}$ & & $0.25^{* * *}$ \\
\hline & & & & & & & \\
\hline & STIE & 1 & 1 & & & 1 & \\
\hline & RCE & $0.70^{* * * *}$ & & $0.70^{* * *}$ & $0.73^{* * *}$ & $0.75^{* * *}$ & $0.70^{* * *}$ \\
\hline \multirow[t]{5}{*}{ EXPLOR } & EXPLOIT & $0.23^{*}$ & $0.32^{*}$ & & & $0.32^{*}$ & \\
\hline & ICE & $0.37^{*}$ & $>$ & & & 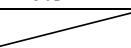 & \\
\hline & WTIE & & $0.45^{*}$ & & & $0.45^{*}$ & \\
\hline & STIE & $0.32^{*}$ & $032^{*}$ & $0.45^{* * *}$ & & $032^{*}$ & \\
\hline & RCE & $0.45^{* * *}$ & & $0.44^{* * *}$ & & & $0.44^{* * *}$ \\
\hline \multirow[t]{6}{*}{ ICE } & EXPLOIT & $0.26^{* * *}$ & $0.31^{* * *}$ & $0.32^{* * * *}$ & & $0.31^{* * *}$ & \\
\hline & EXPLOR & & & $>$ & & & \\
\hline & WTIE & & 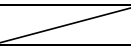 & 1 & & $\longrightarrow$ & \\
\hline & & & & & & & \\
\hline & STIE & 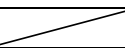 & 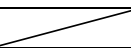 & 1 & & $\longrightarrow$ & $0.80^{* * *}$ \\
\hline & RCE & 7 & & 1 & 7 & & 1 \\
\hline \multirow[t]{5}{*}{ EXPLOIT } & ICE & & & & $0.97^{*}$ & & $0.92 *$ \\
\hline & WTIE & & & 7 & 7 & 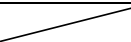 & 1 \\
\hline & EXPLOR & & & $0.67^{* * *}$ & $0.71^{* * * *}$ & & $0.71^{* * *}$ \\
\hline & STIE & & 1 & & & 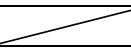 & \\
\hline & WTIE & & 1 & & & 1 & \\
\hline \multirow[t]{2}{*}{ RCE } & ICE & & $0.53^{* * *}$ & & $0.48^{* * *}$ & $0.53^{* * *}$ & \\
\hline & EXPLOR & & $0.53^{* * *}$ & & & & \\
\hline
\end{tabular}




\begin{tabular}{|c|c|c|c|c|c|c|c|}
\hline & & & & & & & Continued \\
\hline & ths & Model 1 & Model 2 & Model 3 & Model 4 & Model 5 & Model 6 \\
\hline & EXPLOIT & & 1 & & & 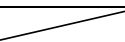 & \\
\hline & & & & & & & \\
\hline & WTIE & & & $0.51^{* * * * 4}$ & $0.51^{* * *}$ & & $0.51^{* \pi *}$ \\
\hline & $\mathrm{ICE}$ & & & & $0.18^{*}$ & & $0.25^{*}$ \\
\hline STIE & EXPLOR & & & 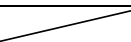 & $>$ & & $>$ \\
\hline & EXPLOIT & & & & $0.17^{* * *}$ & & \\
\hline & RCE & & & 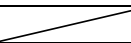 & $>$ & & 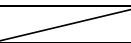 \\
\hline $\begin{array}{l}\text { EXPL } \\
\text { RCE } \\
\text { WTIE } \\
\text { ICE }\end{array}$ & $\begin{array}{l}\leftrightarrow \text { EXPLOI } \\
\text { LORE; ICF } \\
\text { PLORE }\end{array}$ & $\begin{array}{l}\text { WTIE } \leftrightarrow \mathrm{S} \\
\rightarrow \text { EXPLOI }\end{array}$ & ГIE; ICE & & & & \\
\hline
\end{tabular}

In sum, we found supports for recursive positive relationships between weak and strong ties, exploration and exploitation, radical $\mathrm{CE}$ and incremental $\mathrm{CE}$, radical $\mathrm{CE}$ and exploration, incremental $\mathrm{CE}$ and exploitation, weak ties and exploration, and strong ties and incremental CE. However, we did not find the recursive positive relationships between strong ties and exploitation, and radical $\mathrm{CE}$ and weak ties.

\subsubsection{Sample 3 (new ventures in late stage - more than 5 years old)}

All six models were found to be equally plausible solutions with strong fit statistics $\left(\chi^{2}(194)=361.52, p<0.01\right.$; RMSEA $=0.07$; CFI $=0.95 ; \mathrm{IFI}=0.95$; and $\mathrm{NNFI}=0.95$ ). Table 7 shows the relationships among organizational learning, social network, and CE in Sample 3.

Table 7 Summary of relationships in Sample $3(N=168)$

\begin{tabular}{|c|c|c|c|c|c|c|c|}
\hline \multicolumn{2}{|c|}{ Paths } & Model 1 & Model 2 & Model 3 & Model 4 & Model 5 & Model 6 \\
\hline & STIE & $0.42^{* * *}$ & $0.42^{* * *}$ & & & $0.42^{* * *}$ & \\
\hline & RCE & 1 & & $\infty$ & 1 & & 1 \\
\hline \multirow[t]{6}{*}{ WTIE } & EXPLOIT & 1 & & & & & \\
\hline & ICE & 1 & & & 1 & & 1 \\
\hline & \begin{tabular}{|l|} 
EXPLOR \\
\end{tabular} & $0.39^{* * *}$ & & $0.27^{*}$ & $0.28^{*}$ & & $0.28^{*}$ \\
\hline & & & & & & & \\
\hline & STIE & 7 & 1 & & & 1 & \\
\hline & RCE & $0.44^{*}$ & & $0.45^{*}$ & $0.45^{*}$ & $0.64^{* * *}$ & $0.45^{*}$ \\
\hline \multirow[t]{6}{*}{ EXPLOR } & EXPLOIT & $>$ & $0.20^{*}$ & & & $0.20^{*}$ & \\
\hline & ICE & $0.40^{*}$ & 1 & & & 7 & \\
\hline & WTIE & & $0.56^{*}$ & & & $0.56^{*}$ & \\
\hline & & & & & & & \\
\hline & STIE & 1 & 1 & 1 & & 1 & \\
\hline & RCE & 1 & & 1 & & & 1 \\
\hline
\end{tabular}




\begin{tabular}{|c|c|c|c|c|c|c|c|}
\hline \multicolumn{2}{|c|}{ Paths } & Model 1 & Model 2 & Model 3 & Model 4 & Model 5 & Model 6 \\
\hline \multirow[t]{6}{*}{ ICE } & EXPLOIT & $0.27^{* * *}$ & $0.26^{* * *}$ & $0.32^{* * *}$ & & $0.26^{* * *}$ & \\
\hline & EXPLOR & & & 1 & & & \\
\hline & WTIE & & 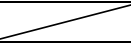 & 1 & & $\longrightarrow$ & \\
\hline & & & & & & & \\
\hline & STIE & 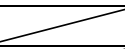 & 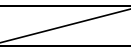 & $0.98^{*}$ & & 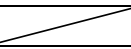 & $1.19^{* * *}$ \\
\hline & RCE & & & 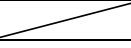 & 1 & & 1 \\
\hline \multirow[t]{6}{*}{ EXPLOIT } & ICE & & & & $1.26^{* * *}$ & & $1.29^{* * *}$ \\
\hline & WTIE & & 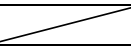 & $0.67^{*}$ & $0.47^{*}$ & 2 & $0.47^{*}$ \\
\hline & EXPLOR & & & & $0.50^{*}$ & & $0.50^{*}$ \\
\hline & & & & & & & \\
\hline & STIE & & 1 & & & 1 & \\
\hline & WTIE & & 1 & & & 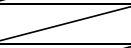 & \\
\hline \multirow[t]{6}{*}{$\mathrm{RCE}$} & ICE & & 1 & & 1 & 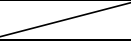 & \\
\hline & EXPLOR & & $0.44^{* * *}$ & & & & \\
\hline & EXPLOIT & & 1 & & & $\longrightarrow$ & \\
\hline & & & & & & & \\
\hline & WTIE & & & $0.27^{* * *}$ & $0.26^{* * *}$ & & $0.26^{* * *}$ \\
\hline & ICE & & & & 1 & & 1 \\
\hline \multirow[t]{3}{*}{ STIE } & EXPLOR & & & 1 & 1 & & 1 \\
\hline & EXPLOIT & & & & $0.19^{* * *}$ & & \\
\hline & RCE & & & $\longrightarrow$ & 1 & & 1 \\
\hline \multicolumn{8}{|c|}{$\begin{array}{l}\text { WTIE } \leftrightarrow \text { STIE; } \\
\text { RCE } \leftrightarrow \text { EXPLORE; ICE } \leftrightarrow \text { EXPLOIT; } \\
\text { WTIE } \leftrightarrow \text { EXPLORE }\end{array}$} \\
\hline
\end{tabular}

In sum, we found supports for recursive positive relationships between weak and strong ties, radical CE and exploration, incremental CE and exploitation, and weak ties and exploration. However, we did not find the recursive positive relationships between exploration and exploitation, radical CE and incremental $\mathrm{CE}$, strong ties and exploitation, radical $\mathrm{CE}$ and weak ties, and incremental $\mathrm{CE}$ and strong ties.

\subsection{Summary}

Most of the recursive positive relationships were supported in the total sample such as those between weak and strong ties, exploration and exploitation, radical $\mathrm{CE}$ and incremental $\mathrm{CE}$, radical $\mathrm{CE}$ and exploration, incremental $\mathrm{CE}$ and exploitation, strong ties and exploitation, weak ties and radical $\mathrm{CE}$, and strong ties and incremental CE. However, for the sub-samples, we just found supports for the recursive positive relationships between weak ties and strong ties, radical $\mathrm{CE}$ and exploration, and incremental CE and exploitation among all the three samples. The recursive positive relationships between exploration and exploitation 
and incremental $\mathrm{CE}$ and strong ties exist not in new ventures more than five years old but in new ventures less than five years old. The recursive positive relationships between weak ties and exploration exist not in new ventures less than three years old but in new ventures more than three years old. The recursive positive relationships between radical $\mathrm{CE}$ and incremental $\mathrm{CE}$ exist just in new ventures more than three years old and less than five years old, but not in others. Therefore, the patterns of major relationships among organizational learning, social network, and CE change during different developmental stages of Chinese new ventures.

\section{Conclusions}

\subsection{Summary of the findings}

This study uses a large sample survey of Chinese new ventures to test the hypothesized models. It was found that all models are plausible solutions across different samples concerning the relationships among the combinations between exploration and exploitation, weak and strong ties, and incremental and radical CE. First, the recursive positive relationships were all supported in the total sample, such as relationships between weak and strong ties, exploration and exploitation, radical $\mathrm{CE}$ and incremental $\mathrm{CE}$, radical $\mathrm{CE}$ and exploration, incremental $\mathrm{CE}$ and exploitation, strong ties and exploitation, weak ties and radical $\mathrm{CE}$, and strong ties and incremental $\mathrm{CE}$. These findings suggest that organizational learning, social network, and $\mathrm{CE}$ intertwine with and reinforce each other in new ventures.

However, we do not find exploration's feedback effect on weak ties. The possible reason is that the feedback effect of exploration on weak ties is mediated by many other factors like exploitation, radical CE, incremental CE, and so on. For example, we found recursive positive relationships between exploration and radical CE as well as between radical CE and weak ties. The findings suggest that exploration is more likely to shape radical CE than to build weak ties since the establishment of tangible weak ties needs a lot of other considerations such as motivation and capability, while, it is relatively much easier to first shape radical CE through exploration and then build weak ties since radical CE can not only motivate but also necessitate the establishment of weak ties.

Unexpectedly, we found recursive positive relationships between weak ties and exploitation although the effect of weak ties on exploration is much greater than that on exploitation and the effect of exploitation on strong ties is much larger than that on weak ties. The findings suggest that, due to lack of industrial clusters, well-developed networks of manufacturing and distribution, and legal 
protection of intellectual property (Lau et al., 2002), the effects of strong and weak ties in many Chinese new ventures are not differentiated clearly and they tend to throw large portions of their available resources, including both strong and weak ties, into exploitation (Luo and Peng, 2000; Xin and Pearce, 1996).

A practical implication for new ventures is that exploration and exploitation, strong and weak ties, incremental and radical CE, though distinct, are not mutually exclusive and they are likely to be intertwined and interdependent so that a new venture benefits from engaging in both types of learning, framing both types of $\mathrm{CE}$, and building both types of social network ties in an ongoing way, depending on the needs of different developmental stages.

Second, for the sub-samples, we just find supports for the recursive positive relationships between weak ties and strong ties, radical $\mathrm{CE}$ and exploration, and incremental $\mathrm{CE}$ and exploitation among all the three samples. Other recursive relationships such as weak ties and exploration and strong ties and exploitation were inconclusive in different samples. These findings suggest that the effects of $\mathrm{CE}$ on organizational learning and organizational learning's feedback effects on $\mathrm{CE}$ are more consistent in new ventures during different stages than those of social network. This may be an interesting finding characteristic of Chinese new ventures that the effects of $\mathrm{CE}$ are more obvious and consistent than those of social network. For example, Li and Atuahene-Gima (2001) found similar results that product innovation strategy is much more important than those of strategic alliance for product development and political networking in Chinese new technology ventures from Beijing Experimental Zone (BEZ), which are most representative of Chinese new ventures. A plausible explanation for this finding is that new ventures in China may have managerial and other problems in leveraging the benefits of such network ties, perhaps owing to lack of experience. Another possible explanation may be that, as a substitute for the inadequate institutional infrastructure, social network's effects have been overemphasized in transition economies such as China (Peng and Health, 1996; Xin and Pearce, 1996). Guthrie (1998) commented on the declining importance of guanxi in China and the increasing realization that "guanxi only helps if you are competitive".

A close examination of the significant recursive relationships in different samples suggests that new ventures less than three years old tend to focus less on such relationships as weak ties, exploration, radical CE and incremental CE and more on those of incremental CE, strong ties, exploration and exploitation owing to the new venture's liabilities of newness and adolescence (Stinchcombe, 1965). For new ventures from three to five years old, owing to increasing experiences and growth motivation (Rhee, 2004), their focus shifts to such relationships as weak ties and exploration, radical CE and incremental CE, although they still keep emphases on both incremental $\mathrm{CE}$ with strong ties and exploration with 
exploitation. Therefore, this period is the most inconclusive stage owing to all kinds of trial and error. Finally, for new ventures more than five years old, after the period of adjustments, they may have a much more clear knowledge on what types of channels or mechanisms facilitate what types of learning and the feedback effects of learning on such channels and mechanisms (Hansen, 1999; Beckman et al., 2004). Also, new ventures at this stage may reach certain balances between radical $\mathrm{CE}$ and incremental $\mathrm{CE}$, exploration and exploitation, and incremental $\mathrm{CE}$ and strong ties and the recursive relationships between them are not significant any more.

A practical implication for new ventures is that, the relationships among organizational learning, social network, and CE play different roles for new ventures during different organizational developmental stages (Oliver, 2001; McGrath, 2001) in that in early stage, new ventures tend to focus more on such relatively stable concepts as exploitation, strong ties, and incremental CE; in the middle stage, they tend to try exploration, weak ties, and radical CE while remain keeping eyes on those relatively stable concepts in the early stage; and finally, they are aware of the clear paths among them and get the balanced relationships among them. In addition, the importance of CE well overcomes that of social network for Chinese new ventures, which is contrary to theoretical arguments made by Peng and Health (1996) and to empirical findings in the west (e.g., Shan, 1990).

\subsection{Contribution of the study}

The central contribution of this paper is to point out that stage does matter concerning the roles of organizational learning, social network, and $\mathrm{CE}$ in Chinese new ventures by integrating and extending these previously disconnected frameworks in the management literature.

First, after a thorough review of existing studies on organizational learning, Huber (1991) expressed critical concerns on the lack of cumulative and integrative research in the field. For example, most existing studies have emphasized that social network and CE would significantly influence the process of organizational learning. However, these studies have tended to treat the effect of social network and that of CE separately and failed to examine their systematic effects on the organizational learning processes (Peng, 2001; Lee et al., 2001), not to mention the feedback effects of organizational learning on social network and CE (Powell et al., 1996). A comprehensive model of the contextual factors that facilitate organizational learning is not yet available (Bapuji and Crossan, 2004). This paper is the first to examine how organizational learning, social network, and CE impact with each other. The findings clearly support that they are interrelated with each other. The evidence obtained in this 
study adds a contribution to the existing literature by opening an interesting avenue to explore the intersections of organizational learning and other organizational theories such as social network and CE.

Second, most social network research remains agnostic with respect to "how social network matters", "under what circumstances", "to what extent", and "in what ways" (Peng, 2000; Rowley et al., 2000). Especially, a hot debate regarding the benefit of strong versus weak ties remains far from consensus (Hong and Antoncic, 2003; Uzzi, 1996). The findings in this study introduce a boundary condition on the assertion that strong ties are most effective for exploitation during the early stage and weak ties are most effective for exploration during the late stage. Despite the fact that research on network effects is far richer and more theoretically nuanced if it examines the dynamic process of network evolution (Delmar and Shane, 2004; Hoang and Antoncic, 2003), little attention has been paid to it (Powell et al., 1996). This paper integrates research on network effects and network dynamics by suggesting that while social network affects organizational learning, organizational learning also affects social network. The findings reveal that exploration is most effective for developing weak ties in the late stage and exploitation is most effective for developing strong ties in the early stage. This evidence provides additional insights to the existing literature of social network by moving beyond the static and fragmented view.

Third, this paper resolves the debate that has long perplexed researchers regarding the effects of different types of CE. Our evidence clearly suggests that radical $\mathrm{CE}$ facilitates exploration and incremental $\mathrm{CE}$ facilitates exploitation during the early, middle, and late stages (Slater and Narver, 1995; Benner and Tushman, 2002). In addition, little research has successfully examined how different types of CE induce organizational learning and organizational learning in turn reshapes different types of CE simultaneously. This paper found that incremental and radical CE significantly affect exploitation and exploration respectively, which in turn reshape and redefine them during the early, middle, and late stages. Thus, our findings provide additional insights to the existing literature of CE by moving beyond the fragmented view (Dess et al., 2003; Kazanjian et al., 2002).

Finally, this paper contributes to literatures of organizational learning, social network, and $\mathrm{CE}$ by adding the evidence in the context of transition economies. For example, most existing studies on exploration and exploitation have been conducted in developed economies (e.g., March, 1991; Kyriakopoulos and Moorman, 2004), research is still very limited in the contexts of transition economies like China (e.g., Boyacigiller and Adler, 1991). Although the idea that social networks matter a great deal in transition economies is hardly controversial (Peng and Luo, 2000; Park and Luo, 2001; Xin and Pearce, 1996; Li and Athuahene-Gima, 2001), recent research suggests that the questions of 
how these social networks matter, under what circumstances, to what extent, and in what ways are still under investigation in the context transition economies (Peng, 2000). Similarly, most studies on CE are conducted primarily in the advanced market economies (e.g., Dess et al., 1997; Zahra et al., 1999), and much less has been done in the context of transition economies. By focusing on a large sample of new ventures in China - one of the largest transition economies, this paper fills this gap.

\subsection{Limitations and suggestions for future research}

The results of this study should be viewed in the context of the following notable limitations, which lay avenues for future research. First, given the large number of new ventures targeted in our data collection, we used a key informant methodology wherein the CEO of each new venture provided survey responses for all the factors. Although such an approach has long been fruitfully used in strategy research (Hambrick and Mason, 1984), the use of multiple informants each new venture might have altered the data. Future research should adopt multiple informants approach to validate information. Second, the use of crosssectional data prevents the direct testing of causality. A true causal ordering needs to be examined using longitudinal data. Third, the exclusive focus on the roles of organizational learning, social network and CE in Chinese new ventures may neglect other important factors that have effects on new venture performance. It has been argued that the determinants of new ventures" success have been associated with founder/manager characteristics, selection of strategy, and access to resources and infrastructure, and so on besides organizational learning, social network, and CE (Lyles et al., 2004). For example, prior studies suggest that limitations from human resources (e.g., turnover, percentage of R\&D employees, etc.), rate of technology change, and environmental turbulence may greatly affect the survival and growth of new ventures. Evaluating these factors will provide greater insights to the literature of new ventures.

Finally, the generalizability of the findings is another area of concern. Using a sample from the population of new ventures in Jiangsu and Guangdong provinces of China, this study finds that organizational learning, social network, and $\mathrm{CE}$ have different roles during different developmental stages. A question may arise as to whether these findings are specific to new ventures in China because the state of knowledge and resource position may differ greatly across countries and regions (Lau et al., 2002). Also the concern may arise as to whether these findings are specific to new ventures or can be applied to large, established organizations. This question is important because they have very different accesses to resources, opportunities, and threats from those of new ventures (Van de Ven and Polley, 1992; Cooper et al., 1991). For example, 
Cooper et al. (1991) found that firm age is positively related with the use of network ties for information helpful to the start of a business venture. Van de Ven and Polly (1992) found that learning does not occur during the initial stage because members involved failed to identify the setbacks. These concerns provide opportunities for future research to choose other organizational populations and to examine whether the findings are generalizable beyond the context of China and new ventures.

Acknowledgements This work is supported by the National Natural Science Foundation of China (No. 70602010) and the "Project of Research on HR Management in Economic Transition and Development" of the Innovation Center for Economic Transition and Development of Nanjing University funded by the National "985 Project".

\section{References}

Anderson J C, Gerbing D W (1988). Structural equation modeling practice: A review and recommend two-step approach. Psychological Bulletin, 103: 411-423

Amburgey T L, Kelly D, Barnett W P (1993). Resetting the clock: The dynamics of organizational change and failure. Administrative Science Quarterly, 38: 51-73

Amburgey T L, Rao H (1996). Organizational ecology: Past, present, and future directions. Academy of Management Journal, 39(5): 1265-1286

Atuahene-Gima K (2003). The effect of exploratory and exploitative market learning on new product performance in new technology ventures: A resource-based perspective. Working paper in City University of Hong Kong

Bapuji H, Crossan M (2004). From questions to answers: Reviewing organizational research. Management Learning, 35(4): 397-417

Barkema H G, Vermeulen F (1998). International expansion through start-up or acquisitions: A Learning perspective. Academy of Management Journal, 41(1): 7-26

Baum J A C (1996). Organizational ecology. In: Clegg S, Hardy C, Nord W (eds.), Handbook of Organizational Studies, 77-114. London: Sage Publications

Baum J A C, Locke E A, Smith K G (2001). A multidimensional model of venture growth. Academy of Management Journal, 44: 292-303

Beckman C M, Haunschild P R, Phillips D J (2004). Friends or strangers? Firm-specific uncertainty, market uncertainty, and network partner selection. Organization Science, 15(3): 259-275

Benner M J, Tushman M L (2003). Exploitation, exploration, and process management: The productivity dilemma revisited. Academy of Management Review, 28(2): 238-256

Bentler P M (1990). Comparative fit indexes in structural models. Psychological Bulletin, 107: 238-246

Bollen K A (1989). Structural Equations with Latent Variables. New York: Wiley

Boyacigiller N, Adler N J (1991). The parochial dinosaur: Organizational science in a global context. Academy of Management Review, 16: 262-290

Brown S L, Eisenhardt K M (1997). The art of continuous change: Linking complexity theory and time-paced evolution in relentlessly shifting organizations. Administrative Science Quarterly, 42: 1-34 
Browne M W, Cudeck R (1993). Alternative ways of assessing model fit, In: Bollen K A, Long J S (eds.), Testing Structural Equation Models, 136-162. Newbury Park, CA: Sage

Bruderl J, Preisendorfer P (1998). Network support and the success of newly founded businesses. Small Business Economics, 10: 213-225

Byrne B (1998). Structural Equation Modeling with LISREL, PRELIS, and SIMPLIS. Mahwah, NJ: Lawrence Erlbaum Associates

Chandler G N, Hanks S H (1994). Market attractiveness, resource-based capabilities, venture strategies, and venture performance. Journal of Business Venturing, 9: 331-349

Cohen W M, Levinthal D A (1990). Absorptive capacity: A new perspective on learning and innovation. Administrative Science Quarterly, 35: 128-152

Collins C J, Clark K D (2003). Strategic human resource practices, top management team social networks, and firm performance: The role of human resource practices in creating organizational competitive advantage. Academy of Management Journal, 46: 740-751

Cooper A C, Folta T, Woo C (1991). Information acquisition and performance by start-up firms, In: Churchill N S et al. (eds.), Frontiers of Entrepreneurship Research, 276-290. Babson Park, MA: Babson College

Covin J G, Miles M P (1999). Corporate entrepreneurship and the pursuit of competitive advantage. Entrepreneurship Theory and Practice, 23(3): 47-63

Covin J G, Slevin D P (1989). Strategic management of small firms in hostile and benign environments. Strategic Management Journal, 10: 75-87

DeGeus A (1988). Planning as learning. Harvard Business Review, 66: 70-74

Dess G G, Ireland R D, Zahra S A, Floyd S W, Janney J J, Lane P J (2003). Emerging issues in corporate entrepreneurship. Journal of Management, 29: 351-378

Dess G G, Lumpkin G T, Covin J G (1997). Entrepreneurial strategy making and firm performance: Tests of contingency and configurational models. Strategic Management Journal, 18(9): 677-695

Delmar F, Shane S (2004). Legitimating first: Organizing activities and the survival of new ventures. Journal of Business Venturing, 19: 385-410

Eisenhardt K M, Schoonhoven C B (1990). Organizational growth: Linking founding team, strategy, environment, and growth among US semiconductor ventures, 1978-1988. Administrative Science Quarterly, 35(3): 504-529

Ensley M D, Pearson A W, Amaso A C (2002). Understanding the dynamics of new venture top management teams cohesion, conflict, and new venture performance. Journal of Business Venturing, 17: 365-386

Galbraith J R (1973). Designing complex organizations. Reading, MA: Addison-Wesley

Granovetter M S (1973). The strength of weak ties. American Journal of Sociology, 78: 13601380

Guthrie D (1998). The declining significance of guanxi in China's economic transition. The China Quarterly, 154(June): 254-282

Hambrick D C, Mason P A (1984). Upper echelons: The organization as a reflection of its top managers. Academy of Management Review, 9: 123-206

Hansen M (1999). The search-transfer problem: The role of weak ties in sharing knowledge across organizational subunits. Administrative Science Quarterly, 44: 82-111

He Z, Wong P (2004). Exploration vs. Exploitation: An empirical test of the ambidexterity hypothesis. Organization Science, 15(4): 481-494

Henderson R M, Clark K (1990). Architectural innovation: The reconfiguration of existing product technologies and the failure of established firms. Academy of Management Journal, 25: $510-531$ 
Hoang H, Antoncic B (2003). Network-based research in entrepreneurship: A critical review. Journal of Business Venturing, 18: 165-187

Huber G P (1991). Organizational learning: The contributing processes and the literatures. Organization Science, 2: 88-115

Ireland R D, Hitt M A, Camp S M, Sexton D L (2001). Integrating entrepreneurship and strategic management actions to create firm wealth. Academy of Management Executive, 15: 49-63

Kazanjian R K, Drazin R, Glynn M A (2002). Implementing strategies for corporate entrepreneurship: A knowledge-based perspective, In: Hitt M A, Ireland R D, Camp S M, Sexton D L (eds.), Strategic Entrepreneurship: Creating a New Mindset, 173-199. Oxford: Blackwell Publishers

Kogut B, Zander U (1992). Knowledge of the firm, combinative capabilities and the replication of technology. Organization Science, 3: 383-397

Kyriakopoulos K, Moorman C (2004). Tradeoffs in marketing exploitation and exploration strategies: The overlooked role of market orientation. International Journal of Research in Marketing, 21: 219-240

Lau C M, Lu Y, Makino S, Chen X, Yeh R (2002). Knowledge management of high-tech firms, In: Tsui A S, Lau C M (eds.), The Management of Enterprises in the People's Republic of China, 183-210. Norwell, MA: Kluwer Academic Publishers

Lawrence P R, Lorsch J W (1967). Organization and environment: Managing differentiation and integration. Homewood, IL: Irwin

Lee C, Lee K, Pennings J M (2001). Internal capabilities, external networks, and performance: A study on technology-based ventures. Strategic Management Journal, 22: 615-640

Levinthal D A, March J G (1993). The myopia of learning. Strategic Management Journal, 14: 95-112

Li H, Atuahene-Gima K (2001). Product innovation strategy and performance of new technology ventures in China. Academy of Management Journal, 44(6): 1123-1134

Lumpkin G T, Dess G G (1996). Clarifying the entrepreneurial orientation construct and linking it to performance. Academy of Management Review, 21(1): 135-172

Luo Y, Peng M W (1999). Learning to compete in a transition economy: Experience, environment, and performance. Journal of International Business Studies, 30: 269-296

Lyles M A, Saxton T, Watson K (2004). Venture survival in a transitional economy. Journal of Management, 30(3): 351-375

March J G (1991). Exploration and exploitation in organizational learning. Organization Science, 2: 71-87

McGrath R (2001). Exploratory learning, innovative capacity, and managerial oversight. Academy of Management Journal, 44: 118-131

Miles R E, Snow C C (1994). Fit, failure, and the hall of fame: How companies succeed or fail. New York: The Free Press

Miller D, Friesen P H (1986). Porter's generic strategies and performance. Organization Studies, 7: 37-56

Morrison E W (2002). Newcomers' relationships: The role of social network ties during socialization. Academy of Management Journal, 45: 1149-1160

Nicholls-Nixon C L, Cooper A C, Woo C Y (2000). Strategic experimentation: Understanding change and performance in new ventures. Journal of Business Venturing, 15: 493-521

Oliver A L (2001). Strategic alliances and the learning life-cycle of biotechnology firms. Organization Studies, 22(3): 467-489 
Olson E M, Walker Jr O C, Ruekert R (1995). Organizing for effective new product development: The moderating role of product innovativeness. Journal of Marketing, 59: 4862

Park S H, Luo Y (1998). Guanxi and organizational dynamics: Organizational networking in Chinese firms. Strategic Management Journal, 22: 455-477

Peng M W (2001). How entrepreneurs create wealth? Academy of Management Executive, 15(1): 95-110

Peng M W, Health P S (1996). The growth of the firm in planned economies in transition: Institutions, organizations, and strategic choice. Academy of Management Review, 21: 492528

Peng M W, Luo Y (2000). Managerial ties and firm performance in a transition economy: The nature of micro-macro link. Academy of Management Journal, 43: 486-501

Pfeffer J, Salancik G R (1978). The external control of organizations: A resource dependence perspective. New York: Harper \& Row

Podsakoff P M, MacKenzie S B, Lee J, Podsakoff N P (2003). Common method biases in behavioral research: A critical review of the literature and recommended remedies. Journal of Applied Psychology, 88(5): 879-903

Podsakoff P M, Organ D W (1986). Self-reports in organizational research: Problems and prospects. Journal of Management, 12: 531-544

Powell W W, Koput K W, Smith-Doerr L (1996). Interorganizational collaboration and the locus of innovation: Networks of learning in biotechnology. Administrative Science Quarterly, 41: 116-145

Rhee M (2004). Network updating and exploratory learning environment. Journal of Management Studies, 41: 933-949

Rowley T, Behrens D, Krackhardt D (2000). Redundant governance structures: An analysis of structural and relational embeddedness in the steel and semiconductor industries. Strategic Management Journal, 21: 369-386

Schumpeter J (1934). The theory of economic development. Cambridge, MA: Harvard University Press

Shane S (2000). Prior knowledge and the discovery of entrepreneurial opportunities. Organization Science, 11(4): 448-469

Slater S F, Narver J C (1995). Market orientation and the learning organization. Journal of Marketing, 59: 63-74

Steiger J H (1990). Structural model evaluation and modification: An interval estimation approach. Multivariate Behavioral Research, 25: 173-180

Stinchcombe A (1965). Social structure and organizations, In: March J G (eds.), Handbook of Organizations, 142-193. Chicago: Rank McNally

Stuart T, Huang H, Hybels R (1999). Interorganizational endorsements and the performance of entrepreneurial ventures. Administrative Science Quarterly, 44: 315-349

Teece D J, Pisano G, Shuen A (1997). Dynamic capabilities and strategic management. Strategic Management Journal, 18: 509-533

Uzzi B (1996). The sources and consequences of embeddedness for the economic performance of organizations: The network effects. American Sociological Review, 61: 674-698

Uzzi B (1997). Social structure and competition in inter-firm networks: The paradox of embeddedness. Administrative Science Quarterly, 42: 35-67

Van De Ven A H, Polley D (1992). Learning while innovating. Organization Science, 3(1): 92-116 
Xin K R, Pearce J L (1996). Guanxi: Good connections as substitutes for institutional support. Academy of Management Journal, 39: 1641-1658

Yli-Renko H, Autio E, Sapienza H J (2001). Social capital, knowledge acquisition, and knowledge exploitation in young technology-based firms. Strategic Management Journal, 22: 587-613

Zahra S A, Ireland R D, Hitt M A (2000). International expansion by new ventures: International diversity, mode of entry, technological learning, and performance. Academy of Management Journal, 43: 925-950

Zahra S A, Nielsen A P, Bogner W C (1999). Corporate entrepreneurship, knowledge, and competence development. Entrepreneurship Theory and Practice, 24: 169-189 